\title{
Hubungan antara Kepribadian, Kesiapan Organisasi untuk Berubah dan Kriteria Universitas Kelas Dunia
}

\author{
Azhar El Hami \\ Universitas Padjadjaran, J1. Raya Bandung-Sumedang KM 21, Jatinangor, 45363 \\ e-mail: azharelhami@gmail.com
}

\begin{abstract}
Changes in the organization is important to retain its existence and continues to grow. This study attempted to see the connection between personality factors (the big five factor), organizational change readiness and the criteria of World Class University at University X. Based on the analysis of qualitative and statistical tests associated with the third link variable, then showed that the personality and organizational change readiness have an important role for the achievement of world class criteria university. This research showed that personality profiles of extraversion and openess to experience as well as aspects of the vision of change and acceptance phase to be decisive for the index of world class university. This result seems to be supported by the presence of the relationship between extraversion profile with aspects of the vision of change and acceptance. The profile of openness to experience also correlated with aspects of vision of change and acceptance.
\end{abstract}

Keywords: the big five personality, organizational change readiness, world class university.

\begin{abstract}
Abstrak
Perubahan dalam organisasi menjadi hal penting agar dapat mempertahankan eksistensinya dan terus berkembang. Penelitian ini berupaya untuk melihat keterkaitan antara faktor kepribadian, kesiapan organisasi untuk berubah dan kriteria universitas kelas dunia di Universitas X. Berdasarkan hasil analisa kualitatif dan juga uji statistik terkait dengan hubungan ketiga variable tersebut, maka didapatkan hasil bahwa kepribadian dan kesiapan organisasi untuk berubah memiliki peran penting bagi tercapainya kriteria universitas kelas dunia. Penelitian ini memperlihatkan bahwa faktor kepribadian extraversion dan openess to experience serta aspek vision of change dan acceptance menjadi penentu bagi pecapaian index universitas kelas dunia. Hasil ini didukung dengan terdapatnya hubungan antara extraversion dengan aspek vision of change dan acceptance. Faktor kepribadian openness to experience berhubungan dengan aspek vision of change dan acceptance.
\end{abstract}

Kata Kunci: kepribadian, kesiapan organiasai untuk berubah, universitas kelas dunia

\section{Pendahuluan}

Setiap organisasi dituntut untuk melakukan perubahan agar dapat tetap bertahan dan kompetitif dalam lingkungan yang dinamis. Perubahan tersebut baik perubahan teknologi, tekanan ekonomi, perubahan kebijakan dan juga proses kerja dari bisnis yang dilakukan (Rachid, 2004). Implementasi dari kesiapan organisasi untuk berubah menjadi salah satu strategi penting yang harus dilakukan oleh sejumlah organisasi dalam menghadapi berbagai respon negatif terhadap perubahan tersebut (Armennakis \& Harris, 2001). Sebuah laporan bisnis mengatakan bahwa banyak organisasi mengalami kegagalan dalam melakukan perubahan juga gagal memperlihatkan peningkatan performa kerja yang diharapkan (Gilmore, et al., 1997). Oleh karenanya kemampuan organisasi untuk melakukan adaptasi terhadap perubahan menjadi isu yang sangat penting. Organisasi harus mampu melakukan adaptasi dengan cepat dan melakukan perubahan jika organisasi tersebut ingin mempertahankan keunggulan kompetitif dan meningkatkan performa organisasi tersebut (Kwahk, 2008).

Kondisi ini tidak jauh berbeda di dunia pendidikan. Tuntutan akan pen-didikan 
yang berkualitas menjadi hal yang sangat penting. Isu-isu mengenai world class university menjadi topik hangat setelah dirilis peringkat dunia universitas terbaik dan beberapa universitas di Indonesia berhasil masuk dalam rangking tersebut. Kondisi ini pun berimbas pada Universitas $\mathrm{X}$ yang merupakan salah satu perguruan tinggi negeri di Indonesia. Universitas $\mathrm{X}$ pada tahun 2007 lalu dalam pidato dies natalis Rektor Universitas X mengatakan bahwa visi Universitas $\mathrm{X}$ saat ini adalah menjadi world class University pada tahun 2026. Banyak perubahan yang dilakukan untuk mencapai tujuan tersebut, baik perubahan yang sifatnya administratif, keuangan, aturan maupun pengembangan sumber daya manusia dan teknologi.

Hanya saja, dalam pelaksanaannya masih sangat jauh dari harapan. Setelah 3 tahun berjalan belum mencapai kemajuan yang signifikan. Banyak hal-hal yang belum menunjang bagi tercapainya perubahan tersebut. Hal ini terutama terkait dengan sumber daya manusia yang masih saja belum menampilkan perilaku yang dapat menunjang bagi tercapainya visi Universitas X. Meski teknologi sudah mulai diterapkan, namun kurang ditunjang dengan pemeliharaan yang optimal. Banyak aturan-aturan yang masih belum dipahami dan dilanggar oleh pegawainya. Para pegawai menganggap bahwa aturan sekarang terlalu ketat dan tidak menunjang bagi cara kerja yang efektif seperti yang telah mereka lakukan sebelumnya. Prosedur kerja yang berlaku dianggap terlalu berbelit-belit dan menyulitkan. Sikap pesimis pun muncul terkait dengan visi universitas tersebut.

Sementara itu, terkait dengan isu world class university, tiap fakultas pun dituntut melakukan perubahan dengan mengarah menjadi world class faculty. Hanya saja pencapaian dari masing-masing fakultas berbeda-beda. Ada fakultas yang saat ini dalam bidang pendidikan telah memiliki internasional class dan twining program. Berbagai kolaborasi penelitian dan juga penerbitan hasil karya stafnya di jurnal- jurnal internasional telah banyak dicapai. Kondisi ini berbeda dengan fakultas lainnya yang hingga saat ini pencapaianya masih belum mengarah pada dunia internasional. Berdasarkan data yang didapat fakultas ini belum memiliki karya ilmiah yang dipublikasikan di jurnal internasional. Dan masih banyak kondisikondisi yang berbeda baik terkait dengan pencapaian fakultas dalam menunjang visi universitas. Jika melihat kondisi yang telah dijelaskan pada bagian sebelumnya, diduga universitas $\mathrm{X}$ masih belum siap untuk melakuan perubahan. Meski ada upaya perubahan sistem yang telah dilakukan, namun dalam pelaksanaanya masih belum berjalan efektif. Selain itu juga belum terjadi perubahan perilaku yang signifikan yang dapat menunjang bagi kelancaran sistem kerja yang telah ditetapkan.

Korbangyang \& Ussahawanitchakit (2009) mengatakan bahwa keberhasilan suatu bisnis ditentukan oleh kesiapan dari organisasi tersebut untuk melakukan perubahan (readiness to change). Amenakis, et. al. (1993) mendefinisikan readiness to change sebagai keterlibatan kepercayaan dan keinginan dari anggota organisasi mengenai seberapa besar perubahan tersebut harus dilakukan oleh mereka dan persepsi mereka terhadap kapasitas individu maupun organisasi untuk mencapai keberhasilan perubahan tersebut. Hal ini merupakan kecenderungan secara kognitif mengenai perilaku yang ditampilkan, apakah menolak atau mendukung upaya perubahan tersebut. A.B. Sutanto (2008) berdasarkan kajiannya terhadap sejumlah penelitian, mengatakan bahwa terdapat tujuh aspek dari change readiness pada sebuah organisasi, yaitu persepsi terhadap upaya perubahan (perception toward change efforts), visi untuk berubah (vision for change), Rasa saling percaya dan menghargai (mutual trust \& respect), Keterlibatan dalam Perubahan (change initiatives), Dukungan Manajemen (management support), Penerimaan (acceptance) dan Pengelolaan proses per- 
ubahan (the organization manage the change process). Persepsi anggota organisasi terhadap perubahan akan menentukan efektifitas dari upaya perubahan tersebut (Armenakis, et al., 1993; Lewin, 1951) dimana persepsi ini akan berpengaruh pada sikap dan keinginan dari para anggota organisasi untuk melakukan perubahan.

Namun, sebuah pertanyaan muncul, siapakah yang memiliki peran penting bagi kesiapan organisasi dalam menghadapi perubahan? Beer \& Nohria (2000) mencatat bahwa hanya $30 \%$ saja organisasi sukses dalam menghadapi perubahan. Alasan kegagalan tersebut karena adanya peningkatan perasaan cemas, emosi yang negatif, ketidakjelasan dan ambiguitas yang muncul diantara para pegawai (Bordia, Hobman, Jones, Gallois, \& Callan, 2004; Kiefer, 2005). Beberapa studi mengenai penolakan terhadap perubahan mencatat bahwa perasaan negatif menjadi indikator dari ketidak inginan karyawan untuk mendukung upaya perubahan dalam organisasi (Applebaum \& Batt, 1993; Judson, 1991). Banyak peneliti yang berupaya untuk menguji seberapa besar peran individu dalam organisasi dan faktor-faktor psikologis yang berdampak pada perubahan (Bray, 1994; Judge, Thoresen, Pucik, \& Welbourne, 1999; Kavanagh \& Ashkanasy, 2006; Schein, 1980; Vakola, Tsaousis, \& Nikolaou, 2004; Wanberg \& Banas, 2000). Schein menyatakan bahwa struktur, hirarki, sistem reward, dan teknologi dimoderatori melalui perubahan dalam diri individu. Berdasarkan perspektif ini, maka kegagalan perubahan disebabkan oleh upaya perubahan tersebut kurang memperhatikan faktor individu, yaitu cognitive-affective nature dari perubahan organisasi (Kavanagh \& Ashkanasy). Schneider, Brief, \& Guzzo (1996) menulis bahwa "If people do not change, there is no organizational change". Oleh sebab itu, perubahan organisasi yang lebih menekankan pada teknologi, struktur dan sistem tidaklah cukup efektif.
Jika lebih mendalam lagi terkait dengan faktor Individu, Schneider (1987), Staw \& Ross (1985) mengatakan bahwa perbedaan individual akan berpengaruh pada reaksi individu pada sebuah perubahan yaitu komitmen untuk berubah. Misalnya saja, individu yang sangat bertoleransi dengan situasi yang tidak jelas (Budner, 1962) seharusnya lebih mampu untuk mengatasi situasi yang tidak menentu akibat perubahan dalam organisasi (Judge et all, 1999). Hal serupa juga terjadi pada individu yang memiliki karakteristik openess to experience (McCrae and Costa, 1986) dan memiliki high self-monitor seharusnya bereaksi lebih positif terhadap upaya perubahan dalam organisasi. Studi lain yang dilakukan oleh Vakola, et al. (2003) didapatkan hasil bahwa kesiapan organisasi untuk berubah yang ditandai dengan sikap terhadap perubahan berkaitan dengan faktor kepribadian (personality trait) dari masing-masing anggotanya. Berdasarkan hal tersebut tampaknya faktor perbedaan individu dalam hal ini kepribadian menjadi faktor penting bagi keberhasilan upaya perubahan dalam organisasi.

Setiap universitas di Indonesia saat ini tengah mengarahkan visi mereka untuk bisa masuk dalam peringkat world class university. Berbagai pembenahan dilakukan untuk dapat mencapaianya, termasuk Universitas $\mathrm{X}$ yang ingin mencapainya di 2026. World Class University memiliki banyak definisi, diantaranya defisini yang diungkapkan oleh Ambrose King (mantan petinggi di Chinese University of Hong Kong) yang mengatakan bahwa world class university adalah suatu term yang mengacu pada aktifitas dari fakultas yang secara rutin mempublikasikan hasil penelitiannya di jurnal-jurnal terkenal di dunia terkait dengan bidang ilmu yang dikajinya; lulusan yang benar-benar berkualitas internasional; para sarjana yang dipekerjakan di seluruh dunia (mohrman, 2005).

Levin, at all (2006) berdasarkan hasil kajiannya mengenai kriteria world class 
university mengatakan bahwa kesubjektifan mengenai kriteria world class univeristy, membuat berbagai lembaga berupaya menggunakan kriteria-kriteria untuk menetapkan reputasi dari sebuah universitas dan melihat pada hal-hal yang bersifat "tampak", sehingga aktifitas penelitian, publikasi penelitian, citation dan penghargaan terhadap fakultas menjadi kriteria yang sering digunakan dalam menentukan reputasi tersebut. Di dunia terdapat berbagai lembaga yang secara khusus memberikan peringkat universitas di dunia dengan kriterianya masing-masing dua diantaranya adalah Shanghai Jiao Tong University (SHJT) dan Times Higher Education Supplement (THES). Pada penelitian ini, world class univeristy dianalogikan sebagai upaya dari fakultas untuk memiliki reputasi secara internasional. Adapun kriteria yang digunakan mengacu kepada kriteria yang digunakan oleh SHJT dan THES, sehingga ditetapkan sebagai berikut : (1) Presentasi Staf pengajar yang pernah memberikan kuliah di luar negeri (JSI), (2) rasio antara jumlah staf pengajar dengan jumlah mahasiswa (RPM), (3) jumlah penelitian yang pernah diterbitkan di jurnal internasional (JPI), (4) prosentase jumlah mahasiswa internasional yang mengikuti pendidikan (JMI) dan (5) jumlah kerja sama internasional yang pernah dijalin (JKI).

Banyak perubahan yang harus dilakukan oleh sebuah organisasi dalam hal ini universitas untuk bisa mencapai world class univeristy ini. Kwahk (2008) mengatakan bahwa suatu organisasi harus mampu melakukan adaptasi dengan cepat dan melakukan perubahan jika ingin mempertahankan keunggulan kompetitif dan meningkatkan performa organisasi. Sebuah studi yang dilakukan oleh Korbangyang \& Ussahawanitchakit (2009) didapatkan hasil bahwa kesiapan menghadapi perubahan (organizational change readiness) berkorelasi positif dengan performa organisasi. Hal ini berarti bahwa semakin siap suatu organisasi untuk berubah (ready to change) maka akan semakin tinggi performa organisasi tersebut.

Armenakis, et al. (1993) menggambarkan readiness to change adalah suatu keyakinan, sikap dan tujuan dari para anggota organisasi mengenai seberapa luas perubahan tersebut diperlukan dan seberapa besar kapasitas keberhasilan organisasi dalam melakukan perubahan. Hal ini merupakan kecen-derungan secara kognitif mengenai perilaku yang ditampilkan, apakah menolak atau mendukung upaya perubahan tersebut. Menurut A.B. Sutanto (2008), berdasarkan kajiannya terhadap sejumlah penelitian, mengatakan bahwa terdapat tujuh aspek dari change readiness dari sebuah orga-nisasi, yaitu persepsi terhadap upaya perubahan (Perception Toward Change Efforts - PCTE), visi untuk berubah (Vision for change - VOC), Rasa saling percaya dan menghargai (Mutual Trust \& Respect - MTR), Keterlibatan dalam Perubahan (Change Initiatives - CI), Dukungan Manajemen (Management Support - MS), Penerimaan (Acceptance Acc) dan Pengelolaan proses perubahan (The Organization Manage the Change Process - MC). Pada intinya, kesiapan untuk ber-ubah sangat terkait dengan transformasi kognitif individu para pegawai (Amenakis, et al., 1993) dalam hal ini bagaimana seseorang mempersepsi dan bersikap terhadap perubahan tersebut.

Penelitian Vakola, Tsaousis \& Nikolaou (2003) didapatkan hasil bahwa terdapat hubungan antara kepribadian (personality trait) dengan sikap terhadap perubahan. Pada penelitian tersebut, mereka menggunakan konsep The Big Five Model yang terdiri dari lima faktor kepribadian, yaitu : extraversion (EXTRA), agreebleness (AGREE), conscientiousness (CONSC), neuroticism (NEURO) dan openness to experience (OPEN). Extraversion mengarah pada tingkat kenyamanan dalam menjalin relasi dengan orang lain. Orang yang extraversion cenderung 
gregarious, asertif dan senang menjalin relasi dengan orang lain. Agreebleness adalah suatu kecenderungan seseorang untuk menghargai orang lain. Sifat-sifatnya ditunjukan dengan perilaku yang kooperatif, hangat dan mudah percaya pada orang lain. Sementara conscientiousness mengacu pada keterandalan seseorang. Hal ini terlihat dari sifat-sifat yang bertanggung jawab, terorganisir dalam bekerja, tekun dan dapat diandalkan. Neuroticism menggambarkan sejauh mana kemampuan seseorang menghadapi situasi menekan. Hal ini dapat menggambarkan mengenai sejauh mana perasaan khawatir, cemas dan bingung pada diri seseorang. Openness to experience adalah suatu kondisi yang menggambarkan seberapa besar minat seseorang dan memiliki daya tarik yang kuat terhadap hal-hal yang baru. Berdasarkan hasil penelitiannya didapat bahwa extraversion, agreebleness, conscientiousness dan openness to experience berhubungan secara positif terhadap sikap terhadap perubahan. Sementara neuroticism berhubungan dengan sikap negatif terhadap perubahan atau dengan kata lain emosional stability berhubungan positif terhadap perubahan.

Integrasi ketiga variable yaitu kriteria world class university, kesiapan organisasi untuk berubah (organizational change readiness) dan kepribadian (personality profile) dibentuk dalam sebuah model pada bagan 1.1 .

\section{Metode Penelitian}

Sampel pada penelitian ini adalah para pegawai di Universitas X (baik dosen maupun tenaga kependidikan). Adapun fakultas yang dijadikan sampel pada penelitian ini adalah fakultas A dan B. Adapun dua fakultas yang dipilih untuk dijadikan sampel penelitian ini dikarenakan adanya asumsi bahwa kedua fakultas ini memiliki perbedaan kesiapan untuk berubah.
Sementara karakteristik sampel pada penelitian ini adalah para pegawai di universitas $\mathrm{X}$ yang telah diterima sebagai pegawai sebelum tahun 2007. Hal ini dengan asumsi bahwa mereka merasakan perubahan yang terjadi setelah penetapan world class university. Adapun teknik sampling yang digunakan pada penelitian ini adalah teknik simple random sampling. Setelah dilakukan pengambilan data, maka terkumpul sebanyak 121 responden, dengan masing-masing dari fakultas A sebanyak 67 orang sementara fakultas B sebanyak 54 orang. Jenis kelamin relatif seimbang diantara laki-laki (57 orang) dan perempuan (64 orang). Tingkat pendidikan paling banyak SLTA (38 orang) dan S2 (33 orang) sisanya berpendidikan $\mathrm{S} 1$ (31 orang), D3 (11 orang), S3 (7orang) dan SLTP (1orang). Sementara untuk kategori usia, sebagian besar responden dari kedua fakultas baik fakultas A dan fakultas B berada pada usia produktif yaitu kelompok usia 25-35 tahun dan kelompok usia 35-45 tahun. 50 orang berusia antara 35-45 tahun, 45 orang berusia antara 25-35 tahun dan 24 orang berusia antara 45-55 tahun. Gambaran masa kerja responden secara umum cukup merata mulai kurang dari 10 tahun (41 orang), 10-20 tahun (49 orang) hingga masa kerja selama 20-30 tahun (39 orang).

\section{Alat Ukur \\ Organizational Change Readiness ini diukur melalui suatu skala yang telah dikembangkan peneliti untuk menjaring data-data mengenai kesiapan organisasi untuk berubah. Alat ukur ini terdiri dari 28 item dengan skala antara 1 sampai 4 (Tidak sesuai-Sangat Sesuai) dengan mengacu pada teori yang disampaikan oleh Sutanto (2008). Menurutnya terdapat 7 dimensi dari kesiapan organisasi untuk berubah, yaitu: (1) persepsi terhadap upaya perubahan (Perception Toward Change Efforts -}


Bagan 1.1.

Model Hubungan antara variable Kepribadian, Organizational Change Readiness \& Kriteria world class university

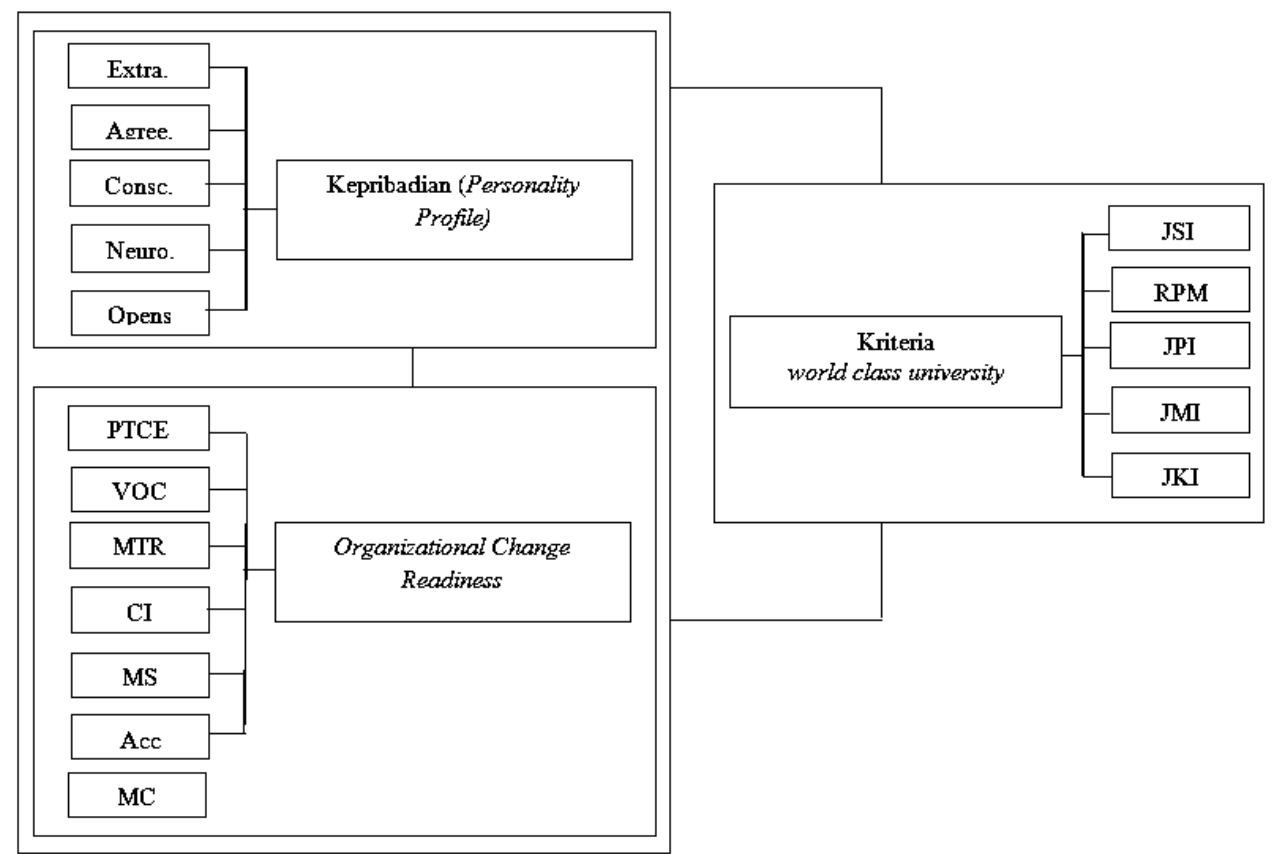

PTCE) yaitu suatu skala yang mengukur tentang bagaimana keyakinan pegawai terhadap perubahan yang terjadi pada organisasinya, (2) visi untuk berubah (Vision for change - VOC) yaitu suatu skala yang mengukur tentang tingkat pemahaman pemahaman pegawai tentang visi dari perubahan. Sementara itu, (3) rasa saling percaya dan menghargai (Mutual Trust \& Respect - MTR) yaitu suatu skala yang mengukur tingkat kepercayaan dan kesediaan para pegawai untuk bekerja sama, termasuk atasan, (4) inisiatif untuk melakukan perubahan (Change Initiatives $C I)$ yaitu suatu skala yang mengukur tingkat keaktifan dari para anggota organisasi dalam mewujudkan perubahan, (5) dukungan manajemen (Management Support - $M S$ ) yaitu suatu skala yang mengukur tingkat dukungan manajemen terhadap perubahan (bisa berupa kebijakan, aturan, sikap pemimpin, kompensasi). (6) Penerimaan (Acceptance - Acc) adalah suatu skala yang mengukur tingkat penerimaan dari pegawai terhadap perubahan dan (7) pengelolaan perubahan (The Organization Manage the Change
Process - MC) mengacu pada suatu skala yang mengukur tentang tingkat perencanaan pengelolaan perubahan yang dilakukan oleh perusahaan/instansi.

Setelah dilakuan uji coba alat ukur dan dihitung secara statistik mengenai reliabilitas alat ukur (OCR), maka didapatkan hasil realibilitas OCR $(0,917)$, PTCE $(0,700)$, VOC $(0,623)$, MTR $(0,705)$, CI $(0,601)$, MS $(0,705)$, Acc $(0,638)$ dan MC $(0,772)$. Sedangkan untuk uji validitas, alat ukur ini menggunakan kriteria expert judgment, sehingga diharapkan bahwa item-item yang ada dapat mengukur kesiapan organisasi dalam menghadapi perubahan. Untuk menentukan kriteria Ready - not Ready maupun masing-masing aspek maka dibuat suatu norma berdasarkan norma kelompok pada Universitas $\mathrm{X}$ yang diambil dari keseluruhan data OCR dari kedua fakultas yang menjadi sampel penelitian.

Kepribadian dalam penelitian ini menggunakan konsep the big five dengan profil kepribadiannya melalui faktor-faktor berikut ini:

Neuroticism. Neuroticism mengarah pada kecenderungan untuk mengalami 
perasaan negatif. Pegawai dengan skor tinggi pada aspek Neuroticism dapat mengalami salah satu dari perasaan negatif seperti cemas, marah atau depresi.

Openness to Experience. Openness menggambarkan suatu dimensi dari gaya berpikir seseorang yang membedakan antara mereka yang imajinatif, berpikir kreaitf, ataupun yang berpikiran konvensional. Pegawai dengan skor tinggi pada aspek Openness memiliki minat yang luas secara intelektual, menghargai seni dan peka terhadap keindahan.

Agreeableness. Agreeableness menggambarkan tentang kepedulian se-seorang akan perbedaan dengan menunjukan sikap kooperatif dan harmonis secara sosial. Pegawai dengan skor tinggi pada aspek agreebleness ini senang untuk bersamasama dengan orang lain di tempat kerjanya, peduli dengan orang lain, ramah, baik hati dan senang membantu serta memiliki kesediaan untuk mengkompromikan minat mereka dengan orang lain.

Extraversion. Extraversion suatu kondisi yang menggambarkan bagai-mana keterlibatan seseorang dengan dunia luar. Orang yang ekstravert senang bersama orang lain, banyak energi dan memiliki emosi yang positif. Orang yang extravert cenderung penuh gairah dan berorientasi pada tindakan.

Conscientiousness. Conscientiousness lebih menggambarkan tentang cara seseorang mengendalikan, meregulasi-kan dan mengarahkan impuls. Pegawai dengan skor conscientious yang tinggi dapat bertindak secara spontan dan impulsif, pribadi yang menyenangkan dan dapat menciptakan suasana kerja menjadi menyenangkan bahkan cen-derung eksentrik.

Kuesioner ini diadaptasi dari the big five inventory (BFI) Oliver P. John (1991) yang kemudian diuji cobakan terlebih dahulu untuk disesuaikan dengan kondisi di Indonesia (alat ukur terlampir). BFI ini terdiri dari 42 item yang mencakup kelima faktor kepribadian. Pada alat ukur ini, responden diminta untuk memberikan tingkat persetujuan (1 sampai 4) terhadap sejumlah karakteristik yang terdapat pada item-item di alat ukur. Setelah dilakukan uji coba, maka didapatkan reliabilitas alat ukur extraversion (0,639), agreebleness $(0,678)$, openness to experience $(0,659)$, conscientiousness $(0,812)$ dan neurotism (0,733). Sementara uji validitas alat ukur untuk BFI, alat ukur ini telah diuji cobakan dalam sebuah riset yang dilakukan oleh John (1991) terhadap alat ukur yang serupa yaitu TDA (Golberg, 1992) dan NEO (Costa \& McCrae, 1992) menunjukan tingkat korelasi pada kategori tinggi pada masing-masing aspek.

Hasil dari alat ukur ini didapatkan suatu profil kepribadian yang bersifat kontinum pada masing-masing faktor. Untuk menentukan kategori dari masingmasing faktor maka digunakan norma kelompok yang didapatkan melalui perhitungan mean dari seluruh data yang didapatkan dari kedua fakultas.

Untuk mengukur pencapaian organisasi maka pada penelitian ini mengacu kepada issue yang tengah berkembang di Universitas X, yaitu world class university. Dengan merujuk pada kriteria yang digunakan oleh dua institusi yang menerbitkan peringkat world class university (THES \& SJTU) dan untuk menentukan pembobotan pada masing-masing kriteria dengan menggunakan expert judgement, maka pada penelitian ini ditetapkan bahwa kriteria world class university adalah (1) Presentasi Staf pengajar yang pernah memberikan kuliah di luar negeri dengan bobot 20\%; (2) Rasio antara jumlah staf pengajar dengan jumlah mahasiswa dengan bobot 10\%; (3) Jumlah penelitian yang pernah diterbitkan di jurnal internasional dengan bobot 30\%; (4) Prosentase jumlah mahasiswa internasional yang mengikuti pendidikan dengan bobot 20\%; (5) Jumlah kerja sama internasional yang pernah dijalin dengan bobot $20 \%$.

Total hasil penjumlahan seluruh kriteria yang ada akan dibagi dengan 5 
(jumlah kriteria) menjadi nilai rata-rata sebagai index kriteria World Class University.

\section{Hasil dan Pembahasan}

Setelah dilakukan pengambilan data terhadap para pegawai di Universitas $\mathrm{X}$ yaitu pada fakultas A dan fakultas B, maka didapatkan hasil bahwa Universitas $\mathrm{X}$ secara umum masih belum siap untuk melakukan perubahan. Hal ini ditunjukan dengan skor kesiapan organisasi untuk berubah (OCR) sebesar 2,784 yang berada dibawah norma kelompok sebesar 2,8. Adapun aspek-aspek yang masih perlu dikembangkan lagi, yaitu (1) Perception Toward Change Effort ( $\mathrm{SPTCE}=2,919$; Norma $=2,93$ ). Ini berarti bahwa para pegawai berdasarkan pengalaman mereka selama ini bekerja di universitas $\mathrm{X}$ masih merasa ragu-ragu mengenai kemampuan organisasi untuk melakukan perubahan menuju world class university; (2)Vision of Change $\quad(\mathrm{SVOC}=2,826 ; \quad$ Norma $=2,841)$. Kondisi ini berarti bahwa pegawai di Universitas $\mathrm{X}$ masih belum paham mengenai tujuan akhir yang ingin dicapai dan pola komunikasi mengenai perubahan tersebut yang masih belum efektif; (3) Mutual Trust \& Respect (SMTR=2,818; Norma=2,826). Hal ini menunjukan bahwa pada aspek ini sikap dari para pegawai masih belum kooperatif terkait dengan perubahan yang terjadi di universitas X; (4) Change Initiative ( $\mathrm{SCI}=2,605$; Norma=2,616). Change Initiative ini mengukur tentang keikut sertaan dari para pegawai guna menunjang perubahan yang tengah terjadi. Jika mengacu pada skor diatas yang berada dibawah norma, maka tampaknya para pegawai di universitas $\mathrm{X}$ cenderung bersikap pasif dalam mengahadapi perubahan; (5) Management Support (SMS=2,71; Norma=2,733). Hasil ini menunjukan bahwa dukungan dari pihak pimpinan/manajemen terhadap proses perubahan masih belum optimal. Dukungan ini bisa berupa aturan, kebijakan, cara memimpin maupun kompensasi yang diterima oleh pegawai seiring dengan terjadinya proses perubahan; (6) Managing Change $\quad(\mathrm{SMC}=2,703 ; \quad$ Norma $=2,719)$, menunjukan bahwa perubahan yang terjadi di universitas $\mathrm{X}$ masih belum terencana dan berjalan secara efektif dan efisien.

Meski demikian, untuk aspek acceptance, yaitu aspek yang menunjukan penerimaan/penolakan terhadap perubahan yang terjadi di dalam organisasi, maka tampaknya secara umum para pegawai di universitas $\mathrm{X}$ menerima perubahan yang terjadi, meski tampaknya penerimaan tersebut lebih banyak berasal dari ketidakberdayaan para pegawai untuk menolak perubahan yang terjadi sehingga apa yang mereka lakukan sekedar menjalankan tugas semata.

Sementara itu, jika dibandingkan antara fakultas A dan fakultas B maka didapatkan bahwa secara umum fakultas B yang merupakan fakultas percontohan universitas $\mathrm{X}$ lebih siap untuk berubah dibandingkan dengan fakultas A. Hal ini dengan melihat nilai skor OCR fakultas B yang berada pada angka 2,818 dan jika dibandingkan dengan norma OCR $(2,8)$ maka hasilnya berada diatas norma. Ini berarti bahwa fakultas B telah siap untuk melakuan perubahan. Sementara di sisi lain, skor OCR fakultas A yang sebesar 2,75 , berada dibawah norma OCR. Hal ini menunjukan bahwa fakultas A masih belum siap untuk melakukan perubahan.

Sementara itu untuk melihat perbedaan kesiapan organisasi untuk ber-ubah (organizational change readiness) antara fakultas A dan B, maka dilakuan pengujian statistik dengan menggunakan kriteria pengujian Mann-Whitney, yaitu tolak Ho jika $\mathrm{p}<0,05$. Hal ini mengingat data-data pada kedua fakultas tersebut tidak terdistribusi secara normal, data bersifat ordinal dan berasal dari dua kelompok yang berbeda. Setelah dilakukan perhitungan dengan menggunakan program software SPSS ver. 13.00 maka didapatkan hasil bahwa $p=0,128$. Ini berarti bahwa tidak ada perbedaan yang signifikan mengenai 
kesiapan organisasi untuk berubah baik pada fakultas A maupun fakultas B.

Sementara setelah dilakukan uji beda pada masing-masing aspek OCR, maka didapatkan hasil bahwa terdapat 2 aspek yang berbeda secara signifikan antara fakultas A dan fakultas B, yaitu pada aspek vision of change $(p=0,002 ; p<0,05)$ dan Acceptance $(p=0,028 ; p<0,05)$. Aspek vision of change merupakan aspek yang menggambarkan sejauh mana kemampuan pihak manajemen mengkomunikasikan visi yang ingin dicapai di masa yang akan datang kepada bawahannya sehingga semua pihak dapat memahami visi tersebut dengan jelas serta paham tentang perubahan yang diinginkan oleh organisasi. Sementara aspek acceptance menggambarkan sejauh mana bawahan menerima atau menolak terjadinya perubahan yang terjadi dalam organisasi.

Pengukuran mengenai kepribadi-an dilakukan dengan memberikan suatu alat ukur yaitu the big five inventory yang terdiri dari 42 item mengenai kelima faktor kepribadian. Setelah data-data BFI (The Big Five Inventory) didapatkan, maka dilakuan perhitungan untuk menetapkan kategori sesuai dengan faktor-faktor yang terdapat di the big five, yaitu Extraversion vs Introversion, Agreebleness vs Antagonism, Conscientiousness vs Lack of Direction, Neuroticism vs Emotional Stability dan Openness vs Closedness to Experience. Adapun hasil dari pengolahan dari datadata yang terkumpul mengenai kepribadian (the big five) lalu dibandingkan dengan norma kelompok maka hasilnya bahwa para pegawai di Universitas X lebih banyak mengarah pada karakteristik introvertion, antagonism, lack of direction, emotional stability dan clossed to experience.

Untuk melihat perbedaan kepribadian pada kedua fakultas yaitu fakultas A dan B, maka dilakukan perhitungan secara statistik dengan menggunakan kriteria uji MannWhitney. Hasil pengujian tersebut dibandingkan dengan kriteria uji $\mathrm{p}<0,5$. Jika $\mathrm{p}<0,5$ berarti tolak Ho maka terima $\mathrm{H} 1$ sehingga terdapat perbedaan yang signifikan diatara kedua fakultas tersebut mengenai faktor kepribadian yang tengah diuji. Hasilnya didapatkan bahwa terdapat perbedaan yang signifikan antara fakultas A dan B pada faktor-faktor kepribadian, yaitu extraversion dan openness to experience. Sedangkan untuk faktor-faktor kepribadian lain yaitu agreebleness, conscientiousness maupun neurotism tidak ditemukan perbedaan yang signifikan antara fakultas A dan B.

Pencapaian organisasi dalam hal ini pencapaian baik fakultas A dan B didapatkan berdasarkan kriteria yang telah ditetapkan sebelumnya dengan mengacu pada kriteria world class university. Pengambilan data untuk pencapaian organisasi dilakukan dengan mencari data-data kepada pihak yang berwenang pada masing-masing fakultas dengan melihat borang akreditasi yang merupakan pencapaian hasil dari masing-masing fakultas sejak tahun 2007-2010. Skor yang didapatkan pada masing-masing kriteria, lalu dijumlahkan dan hasilnya dibagi dengan jumlah kriteria yang ada (5 kriteria). Nilai rata-rata yang didapat merupakan Skor Index World Class University (IWCU). Adapun hasilnya adalah skor IWCU fakultas B sebesar 1,094 lebih tinggi dibandingkan dengan skor IWCU fakultas A sebesar 0,515. Hal ini berarti bahwa pencapaian fakultas B terkait dengan kriteria world class university lebih tinggi dibandingkan dengan pencapaian organisasi fakultas A.

Sementara itu, untuk melihat hubungan antara kepribadian (the big five personality) dengan kesiapan organisasi dalam menghadapi perubahan (orga-nizational change readiness) beserta aspek-aspeknya, maka dilakukan pengujian dengan uji statistik rank-spearment yang perhitungannya menggunakan program software SPSS ver.13.00 maka didapatkan hasil :

Faktor kepribadian agreebleness dan conscientiousness berhubungan positif 
dengan organizational changer readi-ness dan seluruh aspek yang ada pada organizational change readiness.

Faktor kepribadian extraversion berhubungan positif dengan aspek per-ception toward change, vision of change, mutual trust \& respect, change initiative, acceptance dan organi-zational change readiness.

Faktor kepribadian openness to experience berhubungan positif dengan organizational change readiness dan aspek-aspek vision of change, change initiative, acceptance.

Faktor kepribadian neurotism ternyata tidak berhubungan dengan organi-zational change readiness. Sementara jika dilihat pada per-aspek dalam organizatinal change readiness maka neurotism berhubungan negatif dengan perception toward change effort, management support, acceptance.

Untuk melihat hubungan antara Kepribadian, organizational change readiness dengan kriteria world class university, adalah dengan melalui analisis perbandingan secara kualitatif antara fakultas A dan fakultas B untuk seluruh variable yaitu kepribadian, organizational change readiness (OCR) dan kriteria world class university.

Kesiapan organisasi untuk berubah (OCR) pada fakultas A dan fakultas B secara umum tidak berbeda signifikan, namun jika melihat lebih spesifik pada aspek-aspek organizational change readiness (OCR) maka tampak terdapat perbedaan signifikan yaitu pada aspek vision of change $(\mathrm{p}=0,002 ; \mathrm{p}<0,05)$ dan acceptance $(\mathrm{p}=0,028 ; \mathrm{p}<0,05)$. Hal ini pun didukung dengan hasil kategorisasi berdasarkan norma kelompok, dimana pada aspek vision of change, fakultas A berada pada kategori kurang paham tentenag perubahan, sedangkan fakultas B berada pada kategori sudah paham mengenai visi perubahan. Sementara pada aspek acceptance, fakultas $\mathrm{B}$ berada pada kategori menerima, sedangkan fakultas A ber- ada pada kategori menolak. Jika kemudian dikaitkan dengan index world class university (IWCU) yang menunjukan hasil yang berbeda di antara kedua fakultas (IWCU Fak B=1,094 - IWCU Fak $\mathrm{A}=0,515)$, maka keberhasilan fakultas $\mathrm{B}$ jika dikaitkan dengan kesiapan organisasi untuk berubah (organizational change readiness) terletak pada aspek vision of change dan acceptance-nya.

Hasil serupa pun didapatkan ketika membandingkan antara aspek kepribadian (BFI) pada fakultas A dengan fakultas B dimana terdapat perbedaan yang signifikan diantara kedua fakultas yaitu pada aspek kepribadian Extraversion ( $\mathrm{p}=0,21 ; \mathrm{p}<0,05)$ dan Openness to Experience ( $\mathrm{p}=0,042$; $\mathrm{p}<0,05)$. Hal ini pun didukung dengan kategorisasi berdasarkan norma kelompok, dimana pada aspek extraversion, fakultas A berada pada kategori introversion, sedangkan fakultas B berada pada kategori extraversion. Sementara pada aspek Openness to Experience, fakultas B berada pada kategori Openness to experience sedangkan fakultas A lebih berada pada kategori Closedness to Experience. Jika hasil ini dikaitkan dengan nilai index world class university (IWCU) maka tampaknya keberhasilan fakultas B yang mendapatkan nilai index yang lebih tinggi dibandiangkan dengan fakultas A terletak pada aspek kepribadian yang extraversion dan openness to experience.

Sementara itu, dari hasil uji korelasi antara OCR dan BFI maka didapatkan hasil bahwa terdapat hubungan yang positif antara extraversion dengan aspek vision of change $(\mathrm{r}=0,338 ; \mathrm{p}=0,000 ; \mathrm{p}<0,01)$ dan acceptance $\quad(\mathrm{r}=0,369 ; \mathrm{p}=0,00 ; \mathrm{p}<0,01)$. Demikian pula antara openness to experience dengan vision of change $(\mathrm{r}=0,221 ; \mathrm{p}=0,015 ; \mathrm{p}<0,05)$ dan acceptance $(r=0,260 ; p=0,004 ; p<0,01)$.

Penelitian terhadap kesiapan organisasi untuk berubah (organizational change readiness) menjadi bagian penting bagi sebuah organisasi, karena akan berdampak pada keberlangsungan orga-nisasi tersebut 
dimasa yang akan datang. Jika melihat dari hasil penelitian terhadap Universitas $\mathrm{X}$ maka paparan mengenai hubungan antara variable kepribadian, kesiapan organisasi untuk berubah (organi-zational change readiness) dan kriteria world class university adalah seperti pada Bagan 1.2.

Berdasarkan bagan tersebut, maka pada kasus di Universitas $\mathrm{X}$ (dengan sampel fakultas A dan fakultas B), keberhasilan suatu organisasi dalam hal ini sebuah fakultas jika dikaitkan dengan kriteria world class university, dipengaruhi oleh dua aspek dalam kesiapan organisasi untuk berubah (organizational change readiness), yaitu vision of change dan Acceptance. Vision of Change adalah aspek yang melihat sejauh mana perubahanperubahan yang terjadi mampu dikomunikasikan dan dipahami oleh anggota dari organisasi. Sutanto (2008) mengatakan bahwa sebuah visi akan menjadi ketetapan dan kejelasan arah dari sebuah organisasi untuk maju. Tanpa visi yang realistis, upaya transformasi akan berubah menjadi kebingungan dan menjadi proyek yang tidak sesuai bahkan dapat mendorong organisasi ke arah yang salah atau tidak terarah sama sekali (Kotler, 1995). Oleh karenanya, pemahaman yang menyeluruh dari para pegawai terhadap visi dari perusahaan/organisasi serta visi dari perubahan menjadi sangat penting (Sutanto, 2008).

Hal ini lebih tampak terlihat pada fakultas B dimana visi fakultas di masa yang akan datang telah cukup jelas, yaitu to be world class faculty pada tahun 2026. Selain itu, langkah-langkah strategis yang harus dilakukan untuk bisa mencapai tujuan jangka panjang dari fakultas tersebut pun cukup jelas. Target-target yang dicapai pada setiap tahap telah jelas, misalnya saja pada tahun 2016 telah terakreditasi oleh lembaga akreditasi internasional EQUIS
(Eroup Quality Improvement System) sehingga untuk mencapai hal tersebut telah dilakukan pembenahan sistem prosedur kerja yang lebih mengacu kepada standar internasional tersebut. Atribut-atribut promosi menuju world class faculty pun bisa dilihat di berbagai tempat di kampus fakultas $B$ sehingga nuansa keinginan untuk berubah dapat dirasakan. Kegiatankegiatan seperti mendatangkan dosen tamu internasional pun cukup gencar dilaksanakan ataupun mengadakan seminarseminar yang bersifat internasional. Kejelasan akan visi dan juga langkah-langkah yang harus dicapai ini membuat para pegawai di fakultas $B$ paham tujuan fakultas di masa yang akan datang dan membawa mereka untuk mengarahkan segala tindakannya ke sana.

Kondisi berbeda pada fakultas A. Berdasarkan data-data di lapangan melalui hasil interview pada beberapa pegawai di fakultas A, didapatkan bahwa mereka merasa bahwa kriteria world class yang diharapkan oleh fakultas masih belum tergambar dengan jelas. Demikian pula dengan proses sosialisasi yang masih belum gencar baik itu pemasangan atribut-atribut yang menggambarkan tujuan akhir dari fakultas maupun upaya mengadakan forum diskusi guna memberikan kejelasan arah bagi pencapaian fakutas.

Faktor lainnya yang memberikan pengaruh bagi pencapaian organisasi, dalam penelitian ini kriteria world class university, maka aspek Acceptance dalam organizational change readiness memegang peranan penting. Acceptance adalah suatu kondisi yang menggambarkan tentang sejauh mana tingkat penerimaan pegawai terhadap perubahan yang terjadi di dalam organisasi. Ciri telah terjadinya perubahan dalam organisasi adalah dengan melihat dampak dari terselesaikannya suatu 
Bagan 1.2.

Hubungan antara Kepribadian, Organizational Change Readiness \& Kriteria World Class University

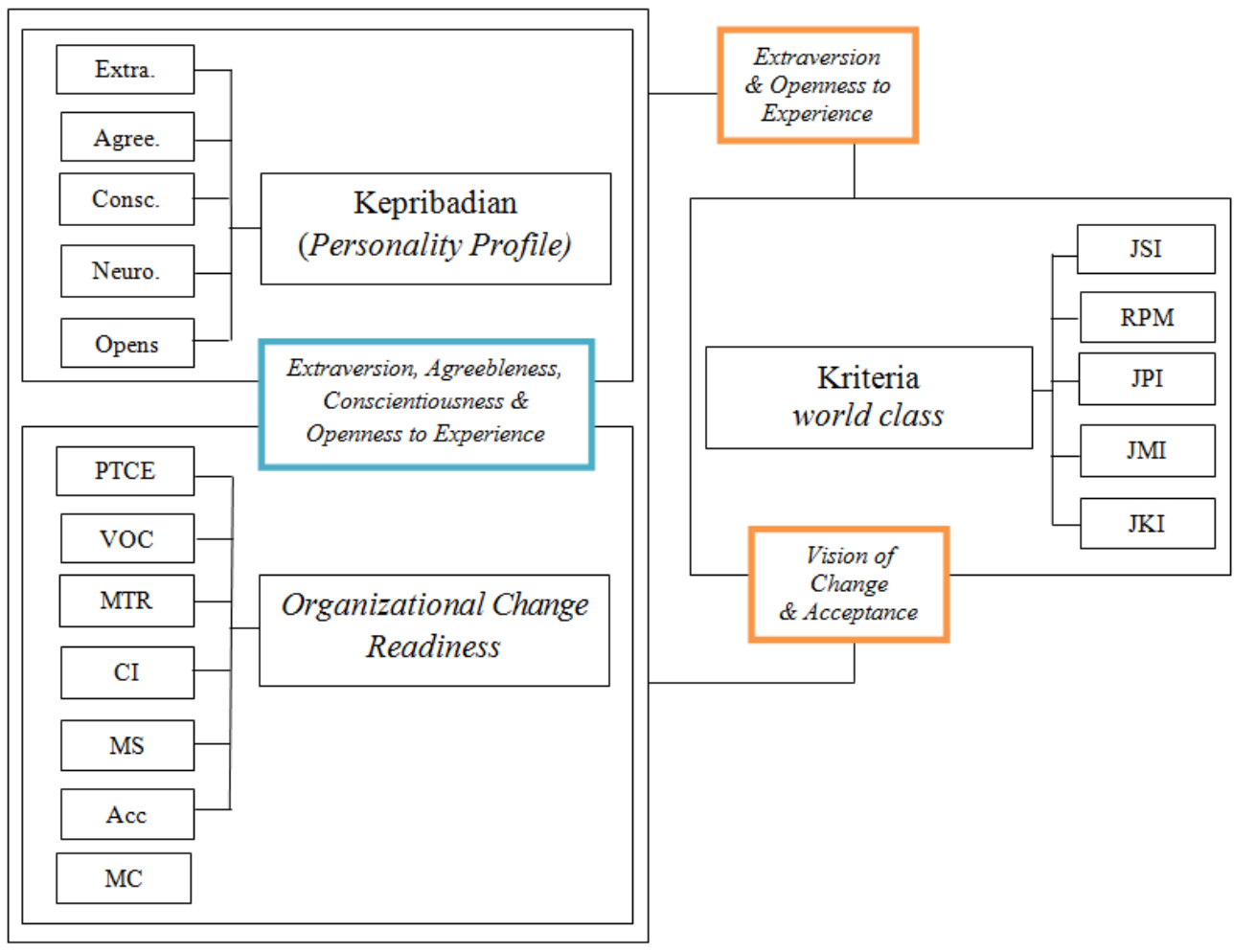

pekerjaan, dalam hal ini pencapaian organisasi, maka reaksi dari pegawai terha-

dap proses perubahan menjadi hal yang sangat penting Eby, et al., (2000). Jika melihat pada Universitas $\mathrm{X}$ maka didapatkan hasil bahwa para pegawai di fakultas B lebih bisa menerima perubahanperubahan yang terjadi dibandingkan dengan fakultas A. Berdasarkan hasil interview dengan beberapa pegawai di fakultas A didapatkan data bahwa mereka cenderung untuk menolak terjadinya perubahan serta lebih pesimis dengan mengatakan bahwa world class university tidak lebih sekedar mimpi yang sulit diraih. Perubahan yang baru sekedar menambah beban bagi pekerjaan yang telah mereka dapatkan tanpa ditunjang dengan kompensasi yang memadai. Sikap-sikap seperti ini yang menjadi kendala bagi upaya perubahan yang dapat menunjang bagi performa yang lebih dalam mencapai visi world class university seperti yang terjadi pada fakultas A.
Sementara jika dikaitkan antara faktor kepribadian dengan kriteria world class university maka tampaknya faktor kepribadian extraversion dan openness to experience menjadi faktor yang dapat mendukung bagi tercapainya kriteria world class university. Data di lapangan menunjukan bahwa fakultas B tampak terkesan lebih terbuka terhadap lingkungan, antusias dengan hal-hal baru serta cepat dalam bertindak yang merupakan ciri-ciri dari karakteristik extraversion. Hal ini terlihat dari telah banyak melaksanakan rencanarencana pengembangan organisasinya ke arah internasional. Misalnya saja telah menjadi anggota dari asosiasi akreditasi internasional dan menjadikan standar dari asosiasi tersebut sebagai acuan standar internasional yang ingin diraihnya ataupun banyak mengundang dosen-dosen dari luar negeri untuk memberikan kuliah. Selain itu, pengirima dosen ke luar negeri untuk mengikuti konferensi maupun mengirimkan hasil penelitiannya pada jurnal bertaraf 
internasional menjadi strategi lainnya guna mencapai visi fakultas. Tentunya tuntutan dunia internasional yang tinggi dengan dengan standar yang ketat diterapkan akan menjadi tantangan tersendiri bagi fakultas B. Sejauh ini fakukltas B lebih suskes untuk bisa memenuhi kriteria/standar tersebut dibandingkan dengan fakultas A. Situasi ini dapat menjadi indikasi bahwa para pegawai di fakultas $B$ cenderung memiliki karaktersitik kepribadian yang openness to experience, lebih siap untuk menerima hal-hal baru. Hal ini pula menjadi indikasi bahwa para pegawai di fakultas B lebih memandang positif terhadap lingkungan yang dihadapinya (extraversion), memiliki energi yang lebih (McCrae \& Costa, 1997), penuh gairah/ passion, memiliki energi yang positif serta berorientasi pada tindakan (Carver \& Scheier, 2000). Kondisi ini berbeda dengan fakultas A yang hingga saat ini masih belum banyak menunjukan gebrakan yang mengarahkan organisasinya menuju international faculty.

Oleh sebab itu, keberhasilan untuk dapat mencapai kriteria world class university bagi Universitas $\mathrm{X}$, akan ditentukan oleh 4 faktor penting, yaitu kepribadian pegawai yang mengarah pada extravertsion dan openness to experience serta aspek dalam kesiapan organisasi untuk berubah (organizational change readiness) yaitu aspek vision of change dan acceptance. Hal ini berarti bahwa semakin banyak pegawai di universitas $\mathrm{X}$ yang menunjukan karakteristik yang terbuka terhadap lingkungan, penuh gairah dan antusias dalam menjalanakn sesuatu serta memiliki energi yang positif dalam menjalin relasi dengan orang lain maka akan semakin mendukung bagi tercapainya kriteria world class university. Demikian pula pada aspek openness to experience yang menggambarkan perilaku pegawainya yang senang dengan tantangan dan hal-hal baru, berpikir kreatif dan imajinatif. Semakin banyak pegawai yang menunjukan karakter openness to experience maka akan dapat memudahkan bagi organisasi untuk bisa untuk memberikan hal-hal baru baik berupa informasi, teknologi ataupun aturan maupun kebijakan yang baru.

Sementara terkait dengan aspek kesiapan organisasi untuk berubah (organizational change readiness), maka tampaknya aspek vision of change menjadi hal yang penting guna menunjang keberhasilan dalam pencapaian kriteria world class university. Semakin jelas dan terarah sebuah perubahan, dan ditunjang dengan cara komunikasi yang baik kepada seluruh karyawan akan membuat karyawan paham tentang pentingnya perubahan dan sejauh mana perubahan tersebut harus dilakukan. Demikian pula dengan penerimaan (acceptance) karyawan terhadap perubahan menjadi faktor yang dapat menentukan keberhasilan organisasi untuk melakukan perubahan guna mencapai visi dan misi yang telah ditetapkan. Semakin besar tingkat penerimaan pegawai terhadap perubahan yang terjadi maka akan semakin mudah pula bagi mereka untuk mengikuti dan menjalankan.

Pada penelitian ini pun didapatkan hasil bahwa kesiapan organisasi untuk berubah (organizational change readiness) terkait erat dengan kepribadian orang-orang yang berada dalam organisasi tersebut. Hasil ini sesuai dengan hasil yang didapatkan oleh Lau dan Woodman (1995) menjelaskan bahwa perbedaan sikap terhadap perubahan dalam organisasi terkait dengan perbedaan individu. Vakola, Tsaousis \& Nikolaou (2003) pun mengatakan bahwa terdapat hubungan antara kepribadian (personality trait) dengan kesiapan organisasi untuk berubah. Lebih detailnya bahwa extraversion, agreebleness, conscientiousness, dan openness to experience berhubungan positif dengan kesiapan organisasi untuk berubah (organizational change readiness). Hanya saja, hasil yang berbeda didapatkan mengenai faktor neurotism yang tidak berhubungan dengan kesiapan organisasi untuk berubah. Hal ini dapat dijelaskan 
bahwa pada Universitas $\mathrm{X}$, para pegawai tidak merespon secara konsisten terkait dengan reaksi emosional terhadap perubahan-perubahan yang terjadi. Jika melihat pada profil lebih mendetail pada fakultas A dan fakultas B, maka terdapat perbedaan reaksi diantara keduanya terkait dengan pencapaian index world class university. Fakultas A dengan kepribadian para pegawainya yang lebih mengarah pada emotional stablilty mendapatkan pencapaian index world class university yang lebih rendah dibandingkan dengan fakultas B yang terdiri dari para pegawai yang juta memiliki ciri kepribadian yang sama. Kondisi ini tampaknya terkait dengan tingkat penerimaan (acceptance) terhadap perubahan yang terjadi pada masing-masing fakultas. Jika melihat hal tersebut tampaknya pada fakultas B emotional stability para pegawai menunjang bagi penerimaan mereka terhadap perubahan dan berdampak pada pencapaian yang lebih baik terkait dengan kriteria world class university. Sedangkan pada fakultas A tampaknya emosional stability yang ditunjukan lebih bersifat pasif-agressive dimana emosinya tidak terekspresikan secara terbuka dan reaksi penolakan merupakan salah satu bentuk agresivitas yang mereka tampilkan (Millon, 1969) terhadap perubahan yang terjadi dalam organisasi. Situasi ini berdampak pada produktivitasnya, dalam hal ini pada pencapaian kriteria world class university yang lebih rendah jika dibandingkan dengan fakultas B.

\section{Pembahasan}

Hasil penelitian ini memberikan kejelasan mengenai keterkaitan antara faktor kepribadian, kesiapan organisasi untuk berubah (organizational change readiness) dan kriteria world class university terutama di Univesitas X. Hal ini memberikan implikasi bagi Universitas $\mathrm{X}$ pada dua sisi, yaitu organisasi dan sumber daya manusia. Pertama dari sisi organisasi tampaknya diperlukan upaya sosialisasi yang sistematis dan terarah untuk mem- berikan kejelasan mengenai visi dari perubahan dan ke arah mana visi tersebut diinginkan oleh Universitas. Kejelasan akan visi ini akan memberikan pemahaman yang lebih komprehensif bagi para pegawai mengenai pentingnya perubahan dalam pekerjaannya maupun langkah-langkah kerja yang harus diambil serta perubahan sikap dan perilaku yang diharapkan dapat mendukung bagi tercapainya visi tersebut. Jika telah terjadi pemahaman yang menyeluruh dan arah yang ingin dicapai, maka energi organisasi pun secara utuh mengarah pada upaya pencapaian visi menjadi world class university.

Proses sosialisasi ini pun akan memberikan dampak pada penerimaan pegawai terhadap perubahan dalam organisasi. Penerimaan dan penolakan terhadap perubahan merupakan faktor penting dalam perubahan organisasi. Sikap menerima akan menjadi faktor penunjang, sementara penolakan berarti kendala bagi organisasi untuk melakukan perubahan. Melalui proses sosialisasi dengan memberikan gambaran mengenai keuntungan jangka panjang yang akan mereka peroleh melalui perubahan organisasi akan memudahkan bagi pegawai untuk menerima perubahan. Ketika mereka merasa bahwa perubahan itu memberikan keuntungan bagi mereka, maka akan menjadi pendorong bagi pegawai untuk menampilkan performa kerja yang maksimal.

Sementara dari sisi sumber daya manusia, tampaknya pengembangan pribadi menuju arah yang extraversion dan juga openness to experience menjadi tema dalam intervensi yang harus dilakukan oleh Universitas X. Intervensi ini bisa dilakukan dengan menciptakan suatu sistem kerja yang mengharuskan para pegawainya melakukan kontak langsung dengan para stake holder atau dengan masyarakan umum. Melalui sistem kerja ini diharapkan agar para pegawai terbiasa untuk bertemu dengan orang-orang baru dan mendapatkan pengalaman baru yang bisa diadaptasi dan diterapkan di dalam bidang tugasnya. 
Pemberian pekerjaan yang berbeda ataupun menantang namun bertahap dapat menjadi alternatif bagi organisasi untuk mengembangkan openness to experience bagi para pegawainya. Penugasan di tempat yang baru akan memberikan kesempatan bagi para pegawai untuk belajar hal baru dan membiasakan diri dengan situasisituasi yang baru. Pemberian pelatihan mengenai kesiapan untuk berubah dengan menekankan pada materi-materi yang mengarah pada pengembangan pribadi terutama terkait dengan extraversion dan openness to experience bisa menjadi alternatif lainnya dalam mempersiapkan pegawai dalam menghadapi perubahan organisasi guna mencapai visi sebagai world class university.

Hanya saja perencanaan intervensi tersebut tidak akan memberikan dampak yang lebih guna mempersiapkan para pegawai dalam menghadapi perubahan jika tidak ditunjang dengan sistem remunerasi yang efektif. Jika mengacu pada teori two factor theory Herzberg maka diperlukan pemenuhan hygiene factor yang dapat menghindarkan para pegawai dari ketidakpuasan, serta mengembangkan motivators factor yang bersifat intrinsik untuk mendorong para pegawai menuju arah kepuasan dalam bekerja. Sejauh ini sistem remunerasi sebagai pegawai negeri sipil bersifat sama rata, bekerja tidak bekerja, produktif-tidak produktif mendapatkan gaji yang sama. Meski sistem ini tidak dapat diubah, namun pemberian tunjangan ataupun insentif terkait dengan produktivitas para pegawai dapat menjadi cara untuk mendorong para pegawai untuk lebih produktif.

Pada penelitian ini terdapat keterbatasan yaitu bahwa sulit untuk menentukan berapa besar kontribsui dari masing-masing variabel yaitu kepribadian dan kesiapan organisasi untuk berubah (organizational change readiness) terhadap pencapaian kriteria world class university dan bagaimana model keterkaitan di antara ketiga variable tersebut. Perbedaan unit analisis antara variable kepribadian dan kesiapan organisasi dengan kriteria world class university menyulitkan untuk dapat secara statistik menentukan kontribusi dari masing-masing variabel. Oleh sebab itu, pengembangan penelitian yang lebih pada level unit analisis yang sama tentunya akan memberikan gambaran yang lebih jelas mengenai keterkaitan diantara ketiga variabel, yaitu: kepribadian, kesiapan organisasi dan kriteria world class university.

\section{Simpulan dan Saran}

Berdasarkan hasil penelitian dan pembahasan yang telah disajikan pada bab sebelumnya, maka dapat disimpulkan bahwa kepribadian para pegawai dalam hal ini extraversion dan openness to experience memiliki keterkaitan dengan tercapainya kriteria world class university pada Universitas X. Extraversion adalah salah satu faktor dalam kepribadian yang menggambarkan tingkat kenyamanan seseorang dalam menjalin relasi dengan orang lain. Pada penelitian ini menunjukan bahwa semakin nyaman para pegawai dalam menjalin relasi dengan orang lain/ lingkungan maka akan berdampak pada pencapaian yang lebih baik dalam kriteria world class university. Kondisi ini tampaknya terkait dengan karakter dari extraversion yang tampak sangat antusias dalam menghadapi segala hal, memiliki energi yang banyak dan cenderung memandang positif terhadap lingkungan sosial. Sikap ini sangat diperlukan ketika sebuah organisasi akan menghadapi perubahan. Bagi sejumlah orang perubahan adalah suatu ancaman, namun bagi individu dengan kecenderungan extraversion maka tampaknya hal tersebut dipandangnya sebagai hal yang positif, mampu mempertahankan sikap antusiasnya secara konsisten dalam menjalankan perubahan serta memiliki energi untuk mengikuti dan melaksankaan perubahan-perubahan tersebut. Kepribadian pegawai yang openness to experience yaitu pegawai yang bersedia 
menerima tantangan, terbuka terhadap halhal baru mau berpikir kreatif menjadi faktor penting juga bagi tercapainya perubahan di Universitas X.

Terkait dengan kesiapan organisasi untuk berubah (organizational change readiness) dengan pencapaian kriteria world class university, maka aspek vision of change dan acceptance menjadi aspek penting yang menunjang bagi tercapainya kriteria tersebut. Aspek vision of change adalah aspek yang menggambarkan kejelasan dari suatu arah perubahan dan bagaimana perubahan tersebut dapat dipahami oleh para pegawai dan cara komunikasi yang efektif bagi organisasi untuk mensosialisasikan perubahanperubahan tersebut. Pada kasus Universitas $\mathrm{X}$ tampaknya keberhasilan dalam proses sosialisasi mengenai visi perubahan dan akan dibawa kemana perubahan tersebut akan menjadi penunjang bagi keberhasilan organisasi dalam mencapai kriteria world class university. Demikian pula dalam hal penerimaan terhadap perubahan (acceptance) yang merupakan salah satu aspek dalam kesiapan organisasi dalam menghadapi perubahan (organizational change readiness) menjadi faktor lain dalam mencapai kriteria world class university. Semakin para pegawai dapat menerima perubahan yang terjadi dalam organisasi, maka akan semakin mudah organisasi tersebut untuk melakukan transformasi menuju arah yang diinginkan.

\section{Daftar Pustaka}

Armenakis, A. A., \& Bedeian, A. G. (1999). Organizational change: a review of theory and research in the 1990s. Journal of Management, 25(3), 293-315

Barrick, M. R., \& Mount, M. K. (1991). The big five personality dimension and job performance: A meta-analysis. Personnel Psychology, 44

Bouckenooghe, D. \& Devos, G. (2007). Psychological Change climate as a catalyst of readiness for change: a dominance analysis. Departement of Management and Entrepreneurship Ghent University

Bouckenooghe, D., Buelens, M. \& Devos, G. (2007). Contribution of content, context, and process to understanding openness to organizational change: two experimental simulation studies. The Journal of Social Psychology, 147(6), 607-629

Brown, C., \& Cregan, C. (2008). Organizational change cynicism: The role of employee involvement. Human Resource Management, Winter, 47(4), 667-686

DeYoung, C. G, (2010). Toward a theory of the big five. Psychological Inquiry, 21, 26-33

Elias, S. M. (2009). Employee commitment in time of change: assessing the importance of attitudes toward organizational Change. Journal of Management, 35(1), 37-55

Ivancevich, G., \& Konopaske, D., (2006). Organization: Behavior, structure, processes., New York: McGraw-Hill Internasional Edition

Judge, T. A., Higgins, C.A., Thoresen, C.J., \& Barrick, M.R. (1999). The big five personality traits, general mental ability, and career success across the life span. Personnel Psychology, 52

Judge, T. A., Illies, R. (2002). Relationship of personality to performance motivation: A meta-analytic review. Journal of Applied Psychology, 87(4), 797- 807

John. O. P., \& Srivastava, S. (1999). The Big-Five Trait Taxonomy: History, Measurement, and Theoretical Perspectives (2nd ed.) Handbook of personality: Theory and research

Kreitner, R. \& Kinicki, A. (2007). Organizational Behavior (7th ed.). New York: McGraw-Hill

Korbangyang, S., \& Ussahawanitchakit, P., (2009). Change readiness and performance of health care service business in thailand: mediator role of 
service excellence, resource exploitation and business competitiveness. International

Business Research, 9(5)

Levin, H. M., Jeong, D. W., \& Ou, D. (March, 2006). What is World Class University?. Conference of the Comparative \& International Education Society, Honolulu

Martin, A. J., Jones, E. S., \& Callan, V. J. (2005). The role of psychological climate in facilitating employee adjustment during organizational change. European Journal of Work and Organizational Psychology, 14(3), 263-289

Major, D. A., Turner, J. E., \& Fletcher, T. D. (2006). Linking proactive personality and the big ive to motivation to learn and development activity. Journal of Applied Psychology, 91(4), 927-935

Rafferty, A. E., \& Griffin, M. A. (2006). Perceptions of organizational change: a stress and coping perspective. Journal of Applied Psychology, 91(5), 11541162

Robins, S. P. \& Judge, T. A. (2007). Organizational behavior (12th ed). Singapore: Pearson International Edition

Roccas, S., Sagiv, L., \& Schwartz, S. H. (2010). The big five personality factors and personal values. Personality and Social Psychology Bulletin, 28(6), 789801

Smith, I. (2005). Achieving readiness for organizational change. Library Management, 26(6/7), 408.

Sutanto, A. B. (2008). Organizational readiness for change: A case study on change readiness in manufacturing company in indonesia. International Journal of Management Perspective

Vakola, M., Tsaousis, I., \& Nikolaou, I. (2003). The role of emotional intellegence $\&$ personality variables on attitude toward organizational change. Journal of Managerial Psychology
Vakola, M., \& Nikolaou, I., (2005). Attitudes towards organizational change : what is the role of employees' stress and commitment? Employee Relation, 27(2), 160-174.

Walker, J. H., Armenakis, A. A., \& Bernerth, J. B. (2007). Factors influencing organizational change efforts An integrative investigation of change content, context, process and individual differences. Journal of Organizational Change Management

Weiner, B. J. (2009). A Theory of Organizational readiness for change. Departement of Health Policy and Management, Gillings School of Global Public Health, University of North Carolina Chapel Hill, North Carolina, USA. Diakses dari http://www.implementationscience.co $\mathrm{m} /$ content/4/1/67 
Psympathic, Jurnal Ilmiah Psikologi Juni 2016, Vol. 3, No. 1, Hal: 95 - 112 